\title{
The Innovative Learning of Square and Rectangle Employing Macanan Traditional Indonesian Game
}

\author{
${ }^{1}$ Padhila Angraini, ${ }^{1}$ Rully Charitas Indra Prahmana* \& ${ }^{2}$ Masitah Shahrill \\ ${ }^{1}$ Mathematics Education, Universitas Ahmad Dahlan, Yogyakarta, Indonesia \\ ${ }^{2}$ Sultan Hassanal Bolkiah Institute of Education, Universiti Brunei Darussalam, Brunei Darussalam \\ ${ }^{2}$ rully.indra@mpmat.uad.ac.id
}

\begin{abstract}
Geometry is one of the essential mathematics materials, such as square and rectangle. However, most elementary school students experience difficulty in understanding it due to the abstractness of the geometric material. Furthermore, teachers teaching in the remote areas of Indonesia still encounter problems exploring this abstract material to make students understand caused by the limited learning resources. On the other hand, students in remote areas are familiar with traditional games, such as Macanan. Hence, the objective of this study is to design learning activities utilizing Macanan game in assisting students understand the concept of the perimeter and area of squares and rectangles for fourth-grade students. A design research approach was implemented and performed at one of the elementary schools in Jambi, Indonesia. The research results presented that Macanan could be a context for a starting point in this learning design of both square and rectangular learning. Employing this context, it would be fun, enjoyable, and easy to understand the perimeter and area of squares and rectangles for students. This game could be a context for teachers in remote areas in teaching geometry and be a reference for identifying other contexts which can make mathematics learning easy in remote areas.
\end{abstract}

Keywords: Design Research, Indonesian Traditional Games, Square and Rectangle, Ethnomathematics.

\section{Introduction}

Mathematics is a basic science which is highly essential in life (Cozzens \& Roberts, 2020; Phoenix, 2018). It is a subject that must be provided to students, from elementary to secondary education (Rowland, 2012; Graham \& Fennell, 2001). However, teachers in schools frequently teach mathematics directly in an abstract form unassociated with daily life or real-world contexts (Chong, Shahrill, \& Li, 2019; Risdiyanti, Prahmana, \& Shahrill, 2019). Hence, students generally experience difficulties, anxiety, meaninglessness, misunderstanding, and misconception with the learned mathematics (Nurhayati, Chang, Naaranoja, 2019; Maschietto \& Trouche, 2010). In essence, mathematics is a human activity (Gravemeijer, 2020; Ernest, 2013), and learning mathematics should be taught in accordance with activities in students' daily lives. Through the activities, students will be able to comprehend the essence of mathematics, expeditiously understand the concept, make meaning, and take advantage of mathematics in solving problems in the students' daily lives (Chong \& Shahrill, 2016; Freudenthal, 1991; Phonapichat, Wongwanich, \& Sujiva, 2014). Therefore, it is essential to teach mathematics with relevant contexts associated with student activities.

Besides the concern on how mathematics is taught in schools, school conditions also influence students' mathematical processes (Acharya, 2017). In Indonesia, not all regions are well developed, wherein some areas are still underdeveloped or frequently referred to as the remote 
areas (Hendayana, Supriatna, \& Imansyah, 2010). These areas are commonly far from urban dwellings, road access to these places is customarily difficult to reach, and Internet access is not available (Hendayana et al., 2010; Kurniati, Arafat, \& Mulyadi, 2020). It makes school facilities and infrastructure difficult to provide and hinders mathematics learning process of students (Kurniati et al., 2020; Febriana et al., 2018). On the other hand, one of the solutions is employing materials around the classrooms or schools to uphold the mathematics learning process for the students so that the mathematics learning process can be conducted optimally in limited conditions (Kusumah \& Nurhasanah, 2017; Hadi, 2002; Zulkardi \& Putri, 2019). Thus, the materials discovered locally can be utilized as context by the students and implemented as starting points in learning mathematics, hence, students will easily understand.

Geometry is one of the most crucial basic mathematics topics, including the concepts of points, lines, shapes, spatial numbers, and others (Laborde, 2015). These concepts are the basis for developing object visualization skills and learning other mathematical concepts in accordance with visual and spatial matters (Laborde, 2015). In daily life, geometry provides means to describe, analyze, and observe mathematical structures (Jones \& Tzekaki, 2016). Besides, geometry studies also contribute to developing mathematical reasoning skills, critical and logical thinking, and analytical skills (Gunhan, 2014). However, students still find it difficult in learning geometry.

Several researchers revealed that in studying geometry, students frequently make mistakes in drawing or visualizing the shapes illustrated, determining the formulas and results, identifying objects based on facts, utilizing symbols, using rules, and interpreting story problems related to geometry in mathematical form (Riastuti, Mardiyana \& Pramudya, 2017; Noto, Priatna, \& Dahlan, 2019; Özerem, 2012, Angraini \& Prahmana, 2019). There are many factors causing students' difficulties, such as teaching mathematics without relating it to students' daily lives, the method which is merely memorizing formulas, and also the low quality or not provided facilities and infrastructure encompassing the lack of teaching material resources and teaching aids (Riastuti et al., 2017; Noto et al., 2019; Özerem, 2012; Angraini \& Prahmana, 2019).

One of the remote areas in Indonesia is in the Village of Pemunyian, Jambi Province. This village is located in an oil palm plantation area which is far from the urban area. Road access is hard to reach by public transportation, and communication access such as telephone or Internet signal is not available. Since access is strenuous to achieve, facilities and infrastructure in schools are hardly to provide. Hence, it has also made learning mathematics difficult at one of the schools at Pemunyian Village, Sunshine Elementary School (a pseudonym). Based on the researchers' observations, students possess predicament in learning mathematics and they do not yet understand some basic mathematics materials, such as number operations and geometry.

In mathematics, there is an approach known as Pendidikan Matematika Realistik Indonesia (PMRI) which is an adoption of the Realistic Mathematics Education (RME) initiated by Hans Freudhental from Utrecht, The Netherlands (Sembiring, Hadi, \& Dolk, 2008; Sembiring, 2010; Fauziah, Putri, Zulkardi, \& Somakim, 2018). PMRI is characterized by utilizing context as a starting point for learning mathematics to guide students to understand mathematical concepts from informal to formal forms (Sembiring et al., 2008; Hadi, 2017; Nasution, Putri, \& Zulkardi, 2018; Sembiring, 2010). The use of familiar and close contexts to students' daily lives makes them easier to imagine mathematical concepts and identify meaningful relations between abstract ideas and the practical applications in the real world (Gravemeijer \& Doorman, 1999; Van den 
Heuvel-Panhuizen, 2005; Risdiyanti et al., 2019). Students also experience easy understanding on the mathematical phenomena from their own perspective and experiences allowing them to obtain meaning from the mathematics they are learning (UNESCO, 2008). In remote areas, mathematics learning can be maximized by the PMRI approach and utilizing the local context in students' daily lives and culture as starting points for learning (Kusumah \& Nurhasanah, 2017).

Therefore, researchers are concerned in developing understanding of square and rectangular shapes in geometry learning designs employing local contexts which are familiar and close to students, which is the Macanan traditional game. The game was applied at Sunshine Elementary School in optimizing mathematics learning in remote areas. The Macanan game is a traditional Javanese game which is also frequently played in Jambi. In this game, some players play as humans and other players play as the tiger, and they attempt to catch each other (Dharmamulya, 2008). Risdiyanti and Prahmana (2018) explained that there is Ethnomathematics in the Macanan game regarding the concepts of odd numbers, geometry, flat shapes, and congruence. Furthermore, entertaining Macanan game also encompass social, cultural, and moral values that students can learn in order to form good student character (Prahmana \& D'Ambrosio, 2020).

Several previous researchers have developed mathematics learning by performing other games such as learning designs using numbers in congklak traditional game (Muslimin, Putri, \& Somakim, 2012); social arithmetic learning using the kubuk manuk game (Risdiyanti et al., 2019); learning number operations employing tepuk bergambar game (Prahmana, Zulkardi, \& Hartono, 2012); learning number operations utilizing bermain satu rumah game (Nasrullah \& Zulkardi, 2011), learning measuring applying patok lele game (Wijaya, 2008), and learning time using gasing game (Jaelani, Putri, \& Hartono, 2013). However, there is a few studies which has implemented the learning design in schools particularly in the remote areas. Therefore, the researchers developed a learning design, employing traditional game contexts, to be implemented in remote areas in optimizing mathematics learning in those areas. Moreover, the learning design is expected to be a reference for mathematics teachers, schools, and researchers and also, may contribute to the cultural perspectives of mathematics education in Indonesia particularly and other countries generally.

The previous studies about squares and rectangles were examined by Haris and Putri (2011) which utilized the context of woven bamboo to teach the area of a square. It was implemented for third-grade students in State Elementary School of 119 Palembang. Furthermore, Wahyuni (2014) was designing the learning trajectory of square and rectangle properties applying the context of lapis legit cake implemented in 7th-grade students at Islamic Junior High School of Hasanah Pekanbaru. On the other hand, the context of Plaid Pattern Cloth (Haryani, Putri, \& Santoso, 2015) and the Reallotment activities (Fitri \& Prahmana, 2018) have been implemented to teach the concept of square and rectangular area for junior high school students. However, all research studies were conducted in urban areas.

\section{Methods}

This study employed a research design method in enhancing the quality of learning practices in the classroom specifically in remote area schools. Research design is defined as a systematic and flexible method for improving the quality of education (Simonson, 2006). Besides, the research design is also defined as a method to develop or validate a learning theory 
(Gravemeijer \& Van Eerde, 2009). This research was conducted through a hypothetical analysis of interactive schemes encompassing students' thinking strategies in the classroom.

There are three stages implemented in this research, which are preliminary design, experimental design, and retrospective analysis (Bakker, 2004; Gravemeijer \& Cobb, 2006). The objective of preliminary design is to formulate a learning trajectory elaborated and refined in the experimental design stage (Plomp \& Nieveen 2013). At this stage, the researcher performs observations on the curriculum applied based on school conditions and designs a Hypothetical Learning Trajectory (HLT), accommodating learning objectives, learning activities, and conjectures or alleged student thinking strategies (Prahmana, 2017). This conjecture provides as a new one which develop in every lesson, is flexible and can be revised during the experimental design stage to adapt to the conditions in the classroom (Van den Akker et al., 2006). After the HLT was designed in the Preliminary Design stage, the HLT was implemented at the experimental design stage to explore students' thinking strategies. Furthermore, in the retrospective analysis stage, the conjectures in the HLT are compared with the results of implementation in the classroom (Plomp \& Nieveen, 2013).

The researchers analyzed the data with the teacher and supervisor to increase the validity of the study. The results are interpreted as a learning trajectory utilizing Macanan traditional game. In the research design, it is not a design which works but how and why the design can work. A retrospective analysis of the HLT design was compared with the learning that has been performed, and the results explain how the square and rectangular concepts were generated from the traditional game, such as a Macanan traditional game.

\section{Remote School Context}

Square and rectangular shape learning designs employing Macanan traditional game were implemented in the Elementary School, Pemunyian Village, Jambi Province, Sumatra Island, Indonesia. The distance between the nearest city of Muara Bungo City to the school is about $52.18 \mathrm{~km}$. It can merely be reached by a land route along $97.1 \mathrm{~km}$ which is unpaved road with a travel time of about 2 hours to 3 hours (Figure 1).

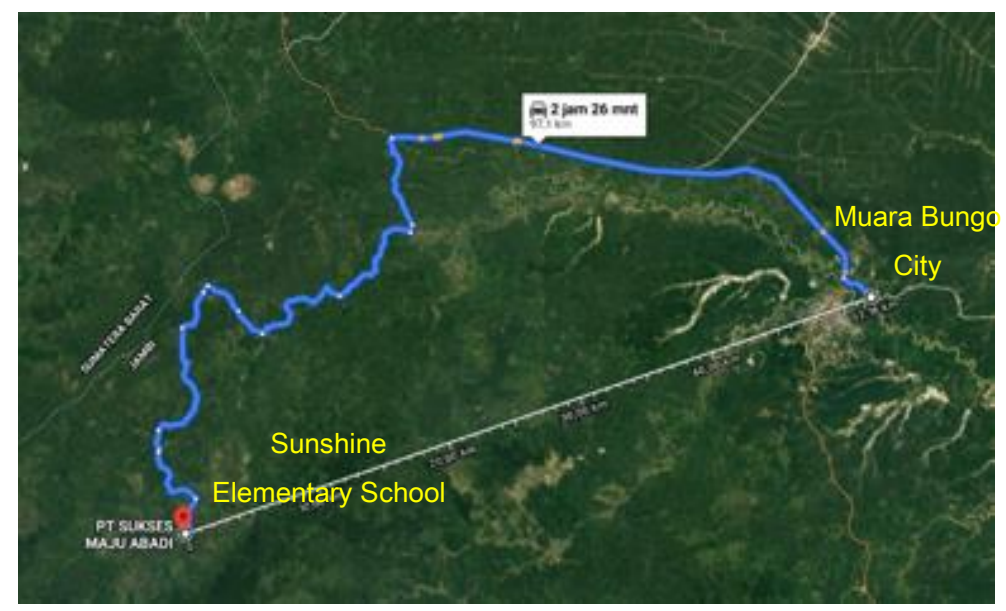

Figure 1. Location of Sunshine Elementary School from Muara Bungo City. 
The roads in the Pemunyian Village area are in the form of rocky soil, making it difficult for people to get in and out of the village. Public transportation cannot reach the village due to the location far from the city, difficult access to public transportation, and non-existent communication access like telephone and internet. Regarding the description, Sunshine Elementary School is known a remote and underdeveloped area. These conditions tremendously affect the Sunshine Elementary School particularly the quality of learning facilities and infrastructure, the educators, and the learning.

Figure 2 contains photos of the Sunshine Elementary School from the front view and in the classroom. In this school, learning resources such as books are seriously limited because access to purchase books in the town is undoubtedly far, and the availability of books in the Muara Bungo City is also limited. Learning resources from the internet cannot be attained by students because there is no internet access at all.
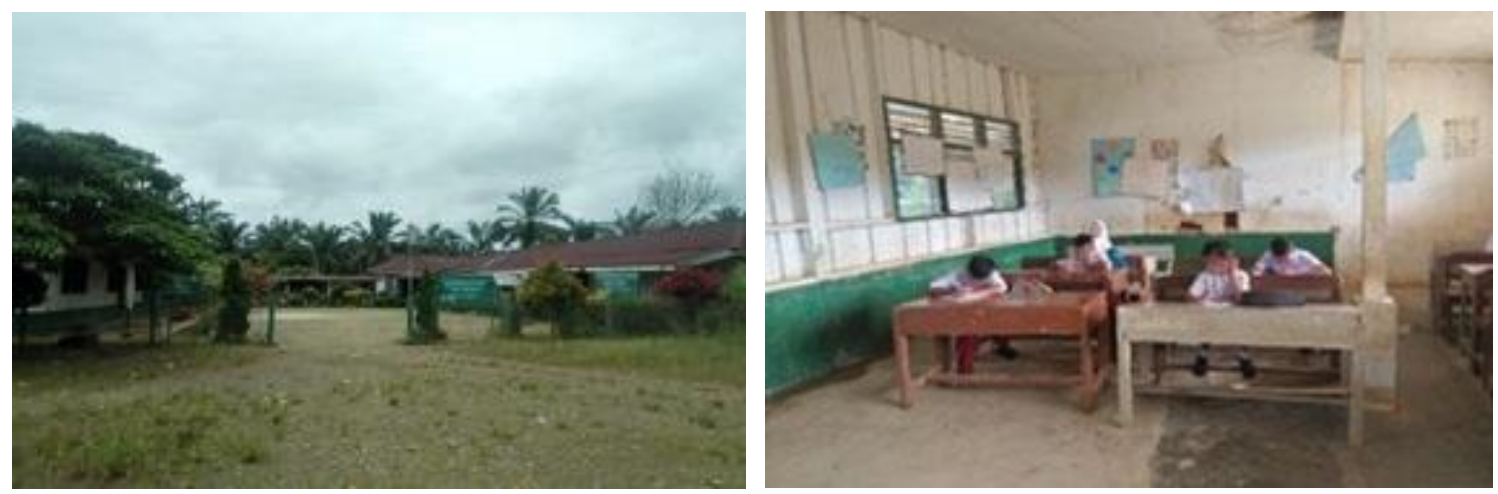

Figure 2. Front view of Sunshine Elementary School (left) and classroom (right).

Parents of students possess a telephone, but the signal is eminently weak and they must walk long distances and up the hill to obtain a signal. Therefore, students primarily depend heavily on teachers' learning resources. However, the teachers' academic qualifications at this school are also low. Some teachers' education is senior high school, and the others graduated from varied majors of bachelor degree but are teaching all courses. In other words, teachers in these schools did not graduate from Primary School Teacher Education department. These conditions have limited the students' learning process, and it is frequently problematic to understand the lesson due to the limited learning facilities and infrastructure as well as inadequate teacher qualifications.

\section{Results and Discussion}

When conducting research at the school, the researcher performed observations to identify curriculum and conditions of students in grade four. Then, the researcher discovered that many students did not understand some basic mathematics material such as number operations regarding addition, subtraction, multiplication, and division. Researchers also unveiled that there were still students who were not good at reading. Besides, the prerequisite materials for learning square and rectangle are like elements in the plane figure that should have been learned by students, but there were still many students who did not understand. It makes it difficult for researchers to implement square and rectangular learning designs utilizing the Macanan game. In solving the problems, before the researcher implemented the learning design, the researcher 
provided treatment by providing private lessons to students as an expectation that students could understand the prerequisite materials first before studying square and rectangular material.

After students understood the prerequisite material, the researcher applied the square and rectangular learning design employing Macanan traditional game as a starting point for learning. The learning design consists of four activities, which are Activity 1, playing Macanan traditional game, Activity 2, identifying the elements and properties of squares and rectangles, Activity 3 , determining the perimeter of the square and rectangle, and Activity 4, determining the area of the square and rectangle. The summary of these activities is presented in Table 1.

Table 1

Summary of Square and Rectangular Learning Activities employing Macanan Traditional Game

\begin{tabular}{|c|c|c|}
\hline $\begin{array}{c}\text { Activity and Learning } \\
\text { Trajectory }\end{array}$ & $\begin{array}{c}\text { Concepts of Square and } \\
\text { Rectangle }\end{array}$ & The Learning Descriptions \\
\hline $\begin{array}{l}\text { Activity } 1 \\
\text { Playing Macanan Traditional } \\
\text { Game }\end{array}$ & $\begin{array}{l}\text { The Shape of Square and } \\
\text { Rectangle }\end{array}$ & $\begin{array}{l}\text { Students play the Macanan game } \\
\text { Students find plane shape in the Macanan } \\
\text { game field } \\
\text { Students present and discuss the result of } \\
\text { finding plane shape in front of the classroom }\end{array}$ \\
\hline $\begin{array}{l}\text { Activity } 2 \\
\text { Identifying the Elements and } \\
\text { Properties of Square and } \\
\text { Rectangle }\end{array}$ & $\begin{array}{l}\text { The Elements and } \\
\text { Properties of Square and } \\
\text { Rectangle }\end{array}$ & $\begin{array}{l}\text { Students cut, past and color the plane shapes } \\
\text { in the Macanan game field. } \\
\text { Students identify elements and properties of } \\
\text { square and rectangles } \\
\text { Students present the results of identifying } \\
\text { elements and properties of square and } \\
\text { rectangle, then continued to class discussion }\end{array}$ \\
\hline $\begin{array}{l}\text { Activity } 3 \\
\text { Determining the Perimeter of the } \\
\text { Square and Rectangle }\end{array}$ & $\begin{array}{l}\text { The Perimeter of Square } \\
\text { and Rectangle }\end{array}$ & $\begin{array}{l}\text { Students solve problem about perimeter of } \\
\text { the square } \\
\text { Students solve problem about perimeter of } \\
\text { the rectangle }\end{array}$ \\
\hline $\begin{array}{l}\text { Activity } 4 \\
\text { Determining the Area of the } \\
\text { Square and Rectangle }\end{array}$ & $\begin{array}{l}\text { The Area of Square and } \\
\text { Rectangle }\end{array}$ & $\begin{array}{l}\text { Students solve problem about area of the } \\
\text { square } \\
\text { Students solve problem about area of the } \\
\text { rectangle }\end{array}$ \\
\hline
\end{tabular}

\section{Activity 1. Playing Macanan Traditional Game}

The first activity is to play Macanan traditional game. The game of Macanan is played by two people employing field games (Figure 3 ) and rock games. The stones are considered people and a tiger. People have to catch the tiger to win, or the tiger eats all people to win. They start from either end of the field, and take turns of moving from one vertex to another. People and the tiger should walk according to the line in the tiger game field. The way people catch the 
tiger is to surround the tiger and have to jump it successfully. When the tiger wants to catch people, it must jump over the people in the game field.

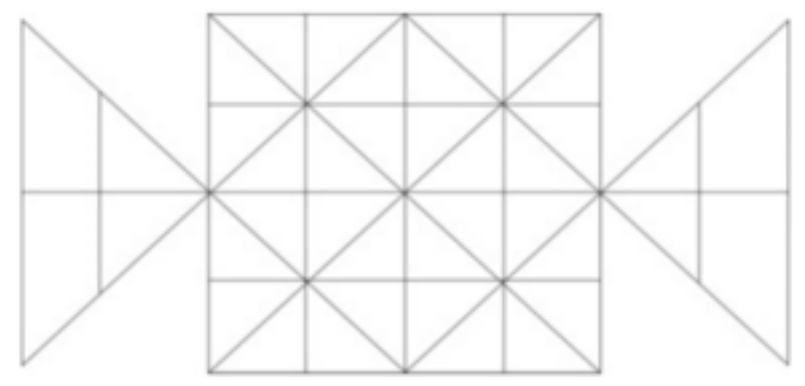

Figure 3. Field of Macanan game.

The objective of this activity is to introduce and equate students' perceptions of the context of Macanan traditional game to help them understand squares and rectangles. Activity 1 comprises of three activities, which are Activity 1.1, students play the Macanan game; Activity 1.2, students find plane shapes in the Macanan game field, cut and past them on the template provided; and Activity 1.3, students present and discuss the result of finding plane shape in front of the class.

\section{Activity 1.1. Students Play the Macanan Game}

The teacher began Activity 1 by exploring students' knowledge about the Macanan game utilized as a learning context, then the teacher explained the activities to be performed. Then, the teacher guided students to create groups of two people. The teacher distributed the Student Activity Sheets (SAS) and invited students to simulate the Macanan game in front of the class. The simulation can be illustrated in Figure 4.

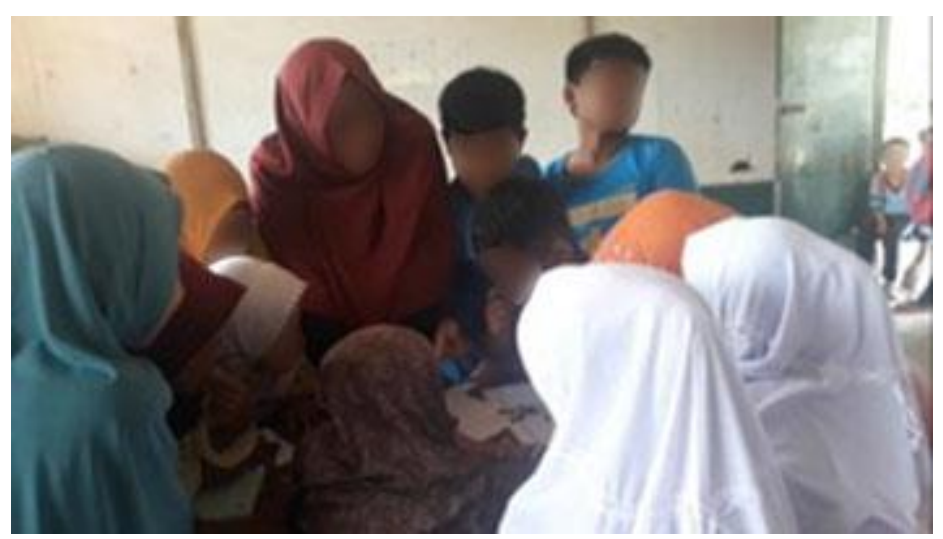

Figure 4. Students and teachers were applying Macanan game.

Once students understood the way to play the Macanan game, each group played the game at their tables (Figure 5). Before starting the game, the students implemented suit to decide to be the tiger (the winner) or the people (the loser). Then, the students were playing in accordance with what was understood during simulations with the teacher. 


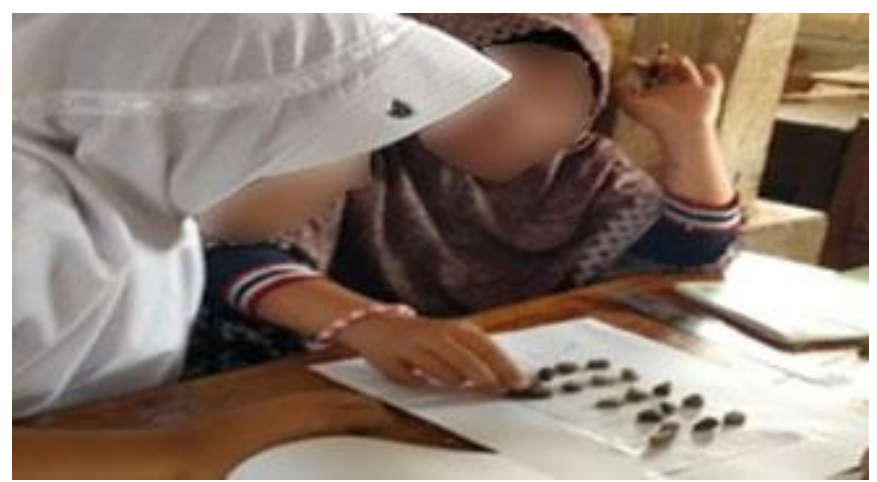

Figure 5. One group of students was playing the Macanan game.

\section{Activity 1.2. Students Find Plane Shape in the Macanan Game Field}

After the students finished playing the Macanan game, the teacher guided them to find planes shapes in the tiger field. Students succeeded in finding plane shapes: squares, rectangles, and triangles (Figure 6).
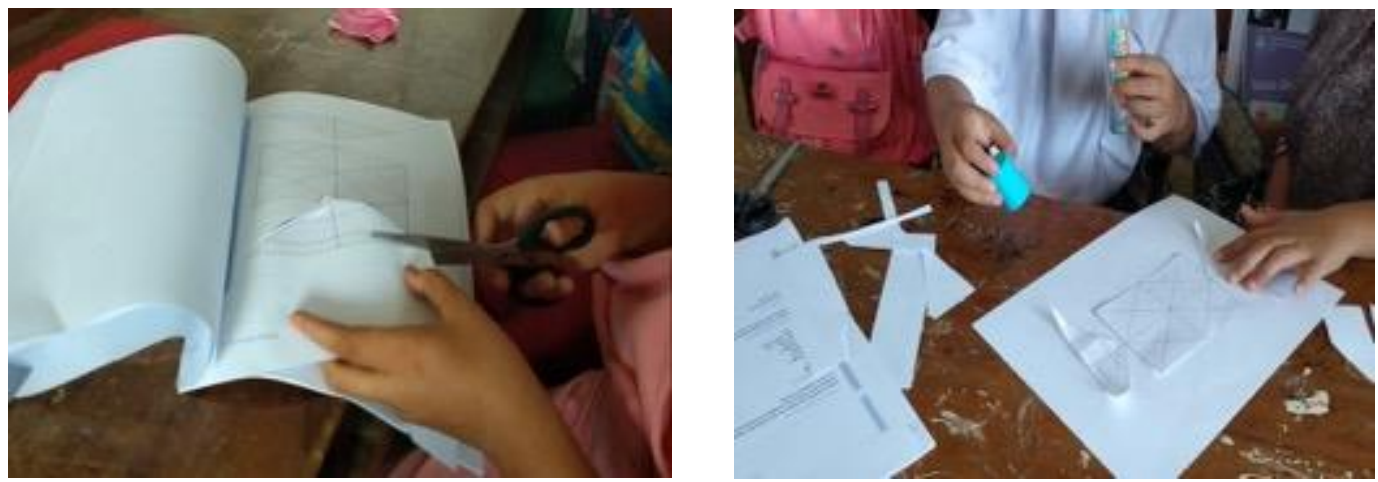

Figure 6. Students were finding plane shapes on the Macanan game field.

\section{Activity 1.3. Students Present and Discuss the Result of Finding Plane Shape in Front of the Class}

The teacher guided students to conduct a class discussion. The teacher instilled the students' responses about the context of the Macanan game by inviting students to look back again at the Macanan game field. Then, the teacher demanded students to present different kinds of plane shapes on the playing field (Figure 7).
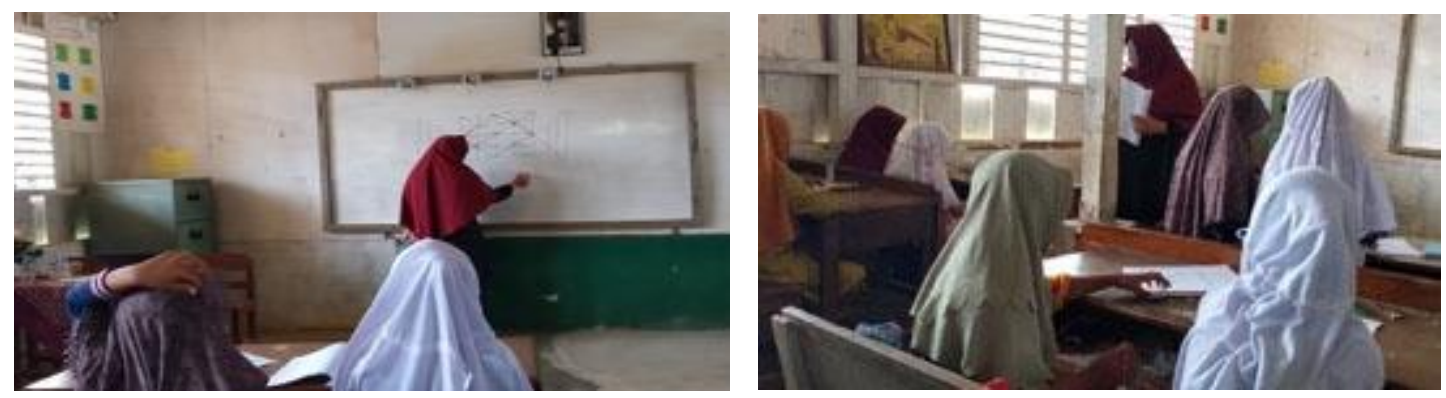

Figure 7. The teacher invited students to look back again at the Macanan game (left) and student with teacher were having a class discussion (right). 
Students then answered with the plane shapes they had discovered: triangles, squares, and rectangles. This activity can be portrayed in Dialog 1 .

Dialogue 1

Teacher : Pada bidang permainan Macanan terdapat bangun datar dengan bentuk apa saja?

[In the Macanan game field, what kinds of plane shapes are there?]

Student : Segitiga, segiempat.

[Triangle, Square]

Teacher : Berapa banyak bangun yang ada pada bidang permainan ini?

[How many planes shapes are there in the Macanan game filed?]

Student : Segitiga, segiempat, segitiga lagi, persegi panjang.

[Triangle, square, triangle again, rectangle]

\section{Activity 2. Identifying the Elements and Properties of Square and Rectangle}

Activity 2 aims to help students understand and identify the elements and properties of squares and rectangles. The elements comprise of lines, diagonals, points, and corners. The objective of this activity is also to help students understand the relation between elements of square and rectangular. Activity 2 consists of several activities which are Activity 2.1 containing students' cutting, pasting, and coloring the plane shapes in the Macanan game field; Activity 2.2, identifying elements and properties of square and rectangles; Activity 2.3, entailing students presenting the results of identifying elements and properties of square and rectangle, then a class discussion. Before these activities began, the teacher allowed students to play the Macanan game first in order to maintain and increase students' motivation so that learning mathematics is fun for students.

\section{Activity 2.1. Student Cut, Past, and Color the Plane Shapes in the Macanan Game Field}

In this Activity 2.1, the teacher began the activity by distributing paper in which there was a picture of the Macanan game field. The teacher instructed students to cut the plane shapes that they have discovered in the game field. Then, the pieces of the plane shapes were being re-attached to the student worksheet. After being attached to the student worksheet, students provide different colors to the plane shapes.
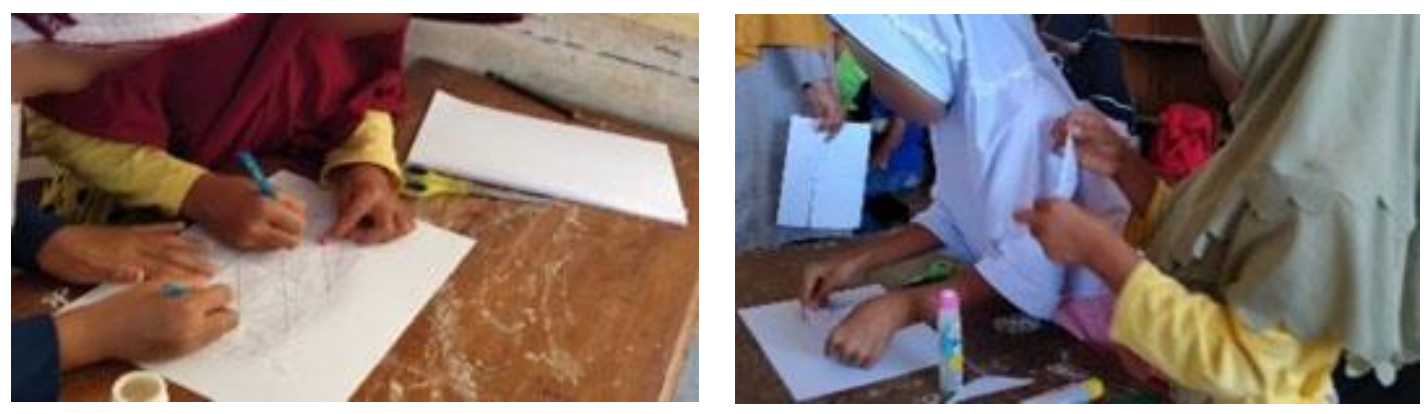

Figure 8. Students were pasting the piece of plane shape (left) and students were coloring the plane shape (right). 
Figure 8 displays students who were pasting and coloring a piece of plane shape on the worksheet. The results of Activity 2.1 can be identified in Figure 9.

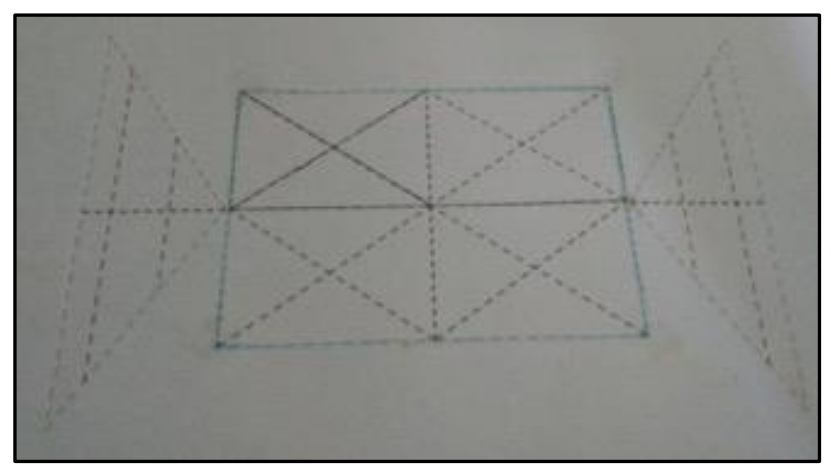

Figure 9. The student result in Activity 2.1.

\section{Activity 2.2. Students Identify Elements and Properties of Square and Rectangles}

In Activity 2.2, the teacher demanded the students to identify the square and rectangular elements such as sides, diagonals, angles, points, and lines. Students made a list of these elements and properties in the column provided in the worksheet. Students could identify the elements of squares and rectangles. They were able to display the elements in form of images, defined in the student's own language, and employed these elements to identify the properties of squares and rectangles. The results were that the students were successful in identifying a square's properties, such as having the same size of each side, having four angles of 90 degrees, and having two diagonals of the same length. The students were also able to identify a rectangle's properties, such as having two long and two wide sides, two diagonals of the same length, and four angles of 90 degrees. It is presented in Figure 10.

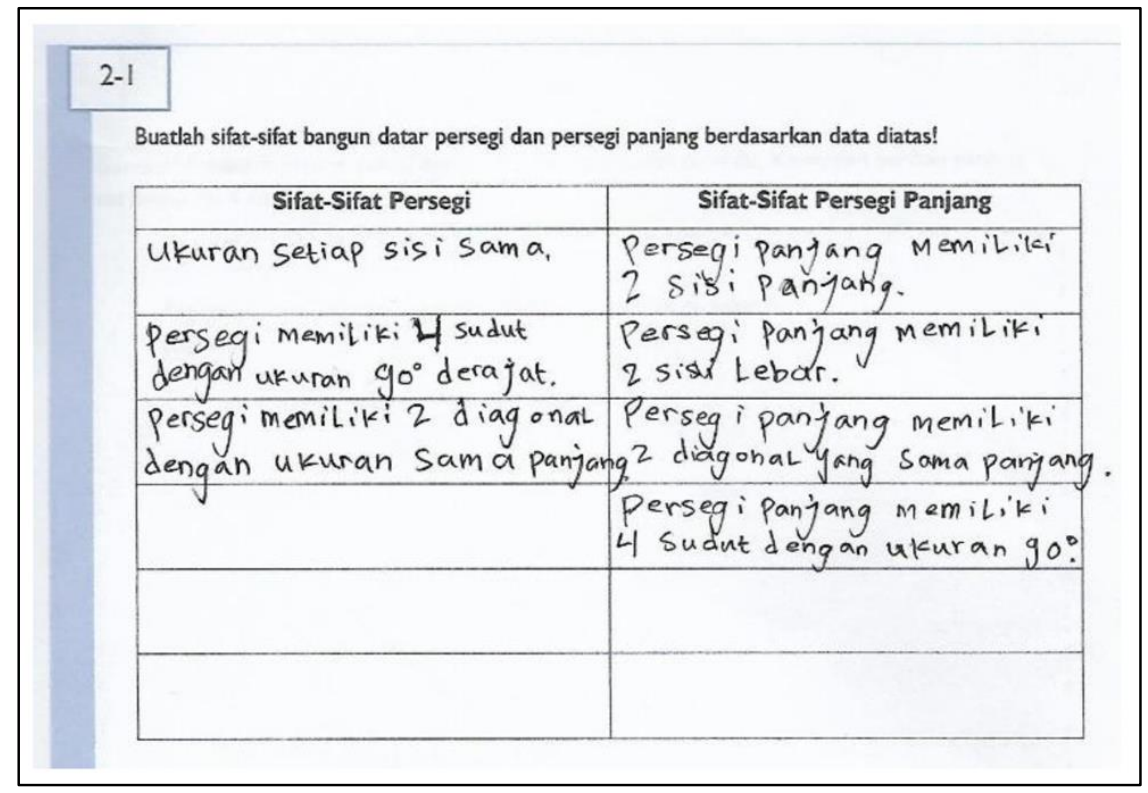

Figure 10. The result of identifying the properties of square and rectangle. 


\section{Activity 2.3. Students Present and Discuss the Results of Identifying Elements and Properties} of Square and Rectangle

After Activity 2.2, students presented the results in front of the class. It aims to explore the various thinking strategies of students. Students produced a picture of the pieces of a plane shape from Activity 2.1, then displayed the squares and rectangles' elements and properties in the shapes they had drawn. Student presentations are presented in Figure 11.
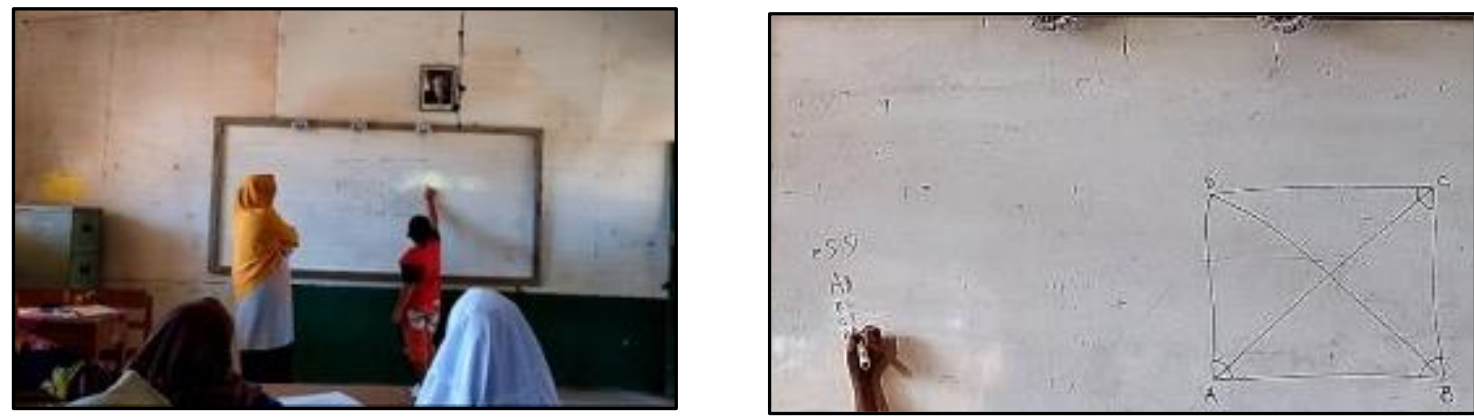

Figure 11. Students were presenting the results of identifying elements and properties of square and rectangle in front of class.

The teacher guided them to conduct class discussions. It aims to equalize perceptions about squares and rectangles' elements and properties. Snippets from class discussions are demonstrated in Dialogue 2.

Dialogue 2

Teacher : Take a look at the pictures you have made, what can be connected from one line to another line? Do you know which side is called and how many are they?

Student : Four.

(Students presented the line which connects the intersection points on the square)

Teacher : When it is known that there are four sides, which side are these? (The teacher provided the corner notation to the square image)

Student : Side is the line connecting A to B, B to C, C to D and D to A. (See Figure 11)

\section{Activity 3. Determining the Perimeter of the Square and Rectangle}

Activity 3 aims to help students understand the perimeter of squares and rectangles. This activity began with the teacher presenting a picture of the Macanan game field and a student worksheet. Then students solved some problems on the student worksheet associated with the Macanan game field on the student worksheet. These problems are as follows.

\section{Problem 3.1. Determining Perimeter of the Square}

Yogi and Varif were playing the game with the position of the rock as displayed in Figure 12. Yogi was as the tiger and Varif was as the people. The stones in the figure were illustrated with dots. The tiger was illustrated with red dot, while black dots represented people. It was 
then connecting the dots on the drawing of the Macanan game area to obtain a plane shape and then provided the shape color. From the plane shape identified, the students were asked whether they could determine the perimeter of the plane shape they discovered on the Macanan game field if they understood that the distance between the points was $4 \mathrm{~cm}$. Then, the students were also demanded to answer the question: what is the perimeter of the plane shape and what is the formula?

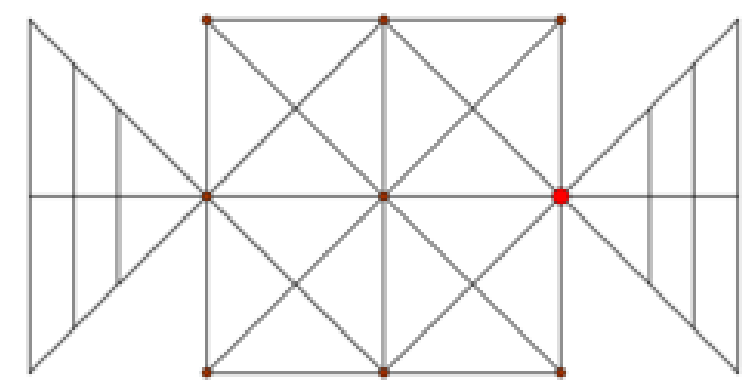

Figure 12. The Macanan game field on Problem 3.1.

After the students obtained an image of the Macanan game field, the students connected the dots on the plane. The result of connecting these points was a square shape. Then, students colored the square shape. After that, students solved the problem and wrote the answers to the student's worksheet which can be identified in Figure 13.

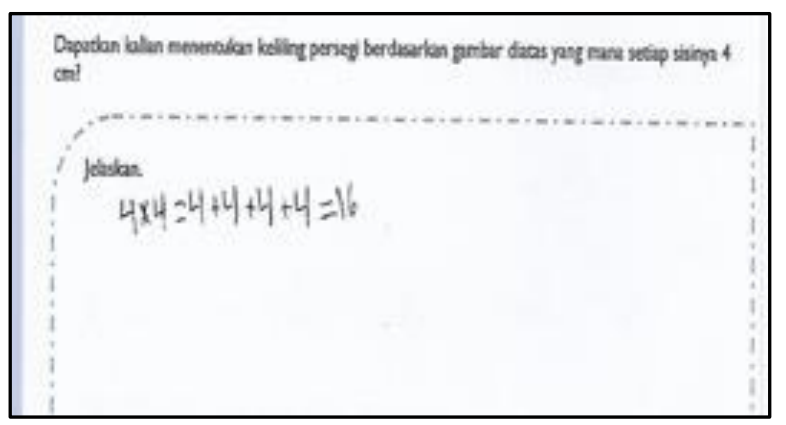

Figure 13. Students' answers of Problem 3.1 for one square of sides $4 \mathrm{~cm}$.

Figure 13 displays that students comprehended the perimeter of a square and could determine it correctly even though they still employed the basic method by adding up all the sides of the square. Hence, it can be concluded that the student has built the understanding on the perimeter of a square and strategies to determine it. Answers and the formula of the square perimeter are presented in Figure 14. 

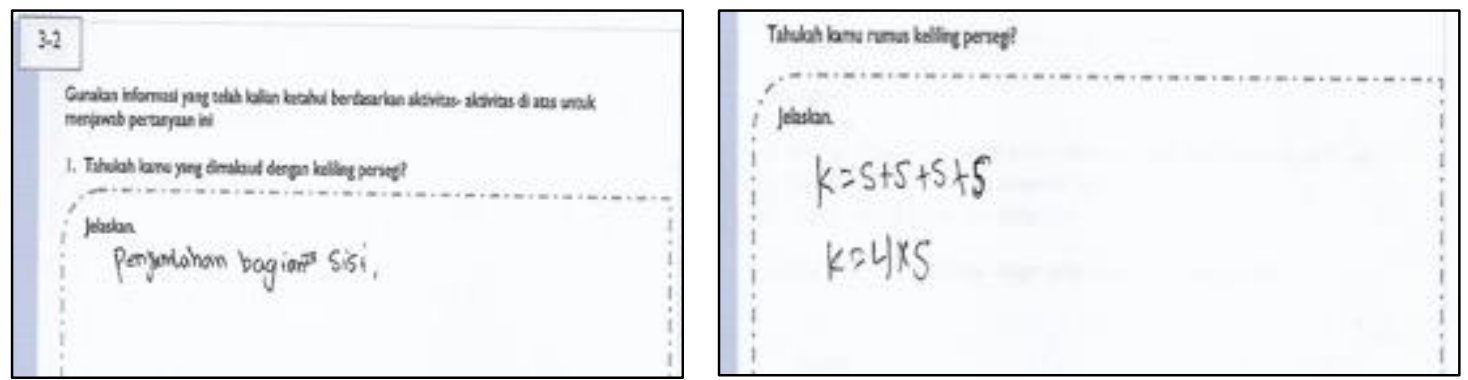

Figure 14. Students' answers for the perimeter and the formula of the square sides $5 \mathrm{~cm}$.

Figure 14 illustrates that the students answered in their own language, the perimeter of a square is the sum of the sides of the square. The students determined the perimeter formula by adding the sides of the square 4 times. The students were also able to explain the formula in formal form. Based on this answer, it can be concluded that the students had understood the definition and formula of the perimeter of a square.

\section{Problem 3.2. Determining Perimeter of the Rectangle}

Jeni and Selfi were playing the game with the position of the rock presented in Figure 15. Jeni was as the tiger and Selfi was as the people. The stones in the figure were illustrated with dots. The tiger and the people were illustrated with black dot and red dots respectively. They connected the dots on the drawing of the Macanan game area to obtain a plane shape and then provided the shape color. From the plane shape discovered, they students had to answer whether they could explain what was meant by the long side and the wide side, what the perimeter of the plane shape was, and what the formula was.

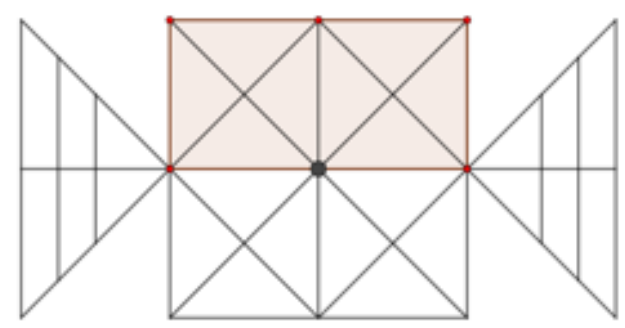

Figure 15. The Macanan game field on problem 3.2.

The result of connecting and coloring the rectangle was subsequently employed by students to solve the problem and write the answers to the students' worksheet as displayed in Figure 16. It indicates that students have answered using their own language that the long side is the longest side, and the wide side is the shortest side. 

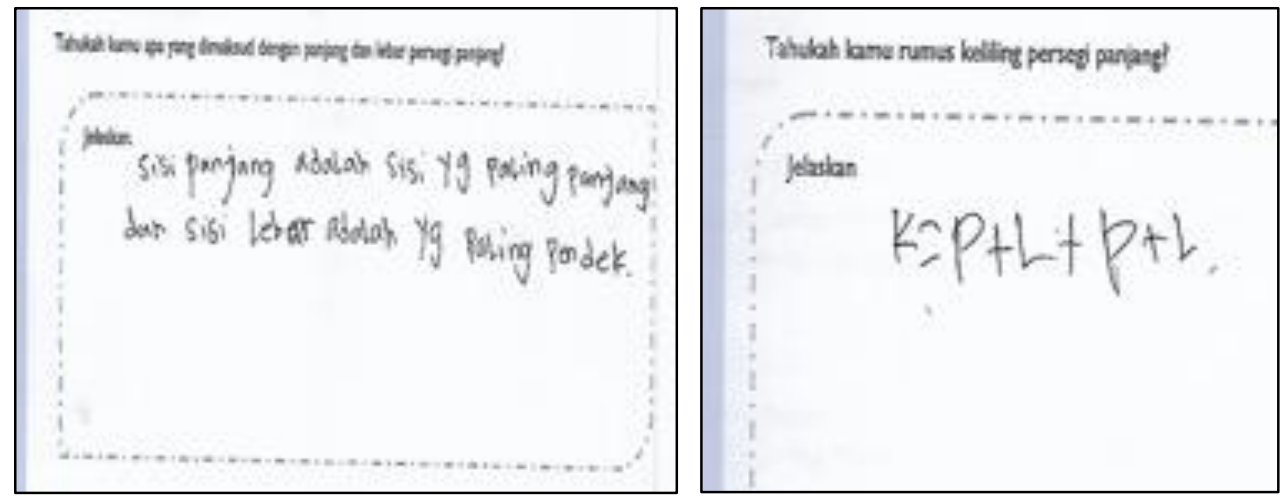

Figure 16. Students' Answers of Problem 3.1.

Students also understood how to determine the perimeter of a rectangle and write the formula in formal form. However, students still found difficulties in defining the perimeter of a rectangle. The teacher then clarified that the definition of the perimeter of a rectangle was determined by adding the sides of the rectangle or by adding twice the length plus twice the width of the rectangle.

\section{Activity 4. Determining the Area of the Square and Rectangle}

Activity 4 aims to help students understand the area of squares and rectangles. This activity began with the teacher providing a picture of the Macanan game field and student worksheet. Then students solved several problems on the student worksheet associated with the Macanan game field on the student worksheet. These problems are as follows.

\section{Problem 4.1. Determining Area of the Square}

Jeni and Selfi were playing the game with the position of the rock as follows (Figure 17). Jeni was as the tiger and Selfi was as the people. The stones in the figure were illustrated with dots. The tiger and the people were illustrated with black dot and red dots respectively. They connected the dots on the drawing of the Macanan game area to obtain a plane shape and color the shape. From this plane shape, they were demanded to answer whether they could determine how many tiles there were in the Macanan game field, given the side length was $6 \mathrm{~cm}$, what the area of the plane shape was, and if it was identified that the side length was $7 \mathrm{~cm}$, what the area of the plane shape was.

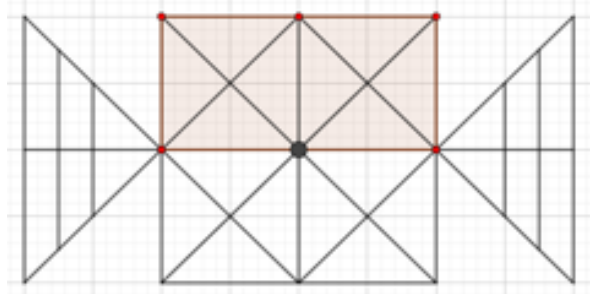

Figure 17. The Macanan game field on Problem 4.1.

After connecting the points, a square shape is obtained, and then students colored the rectangle. Then, students solved the problem and wrote the answers to the students' worksheet which can be observed in Figure 18. 

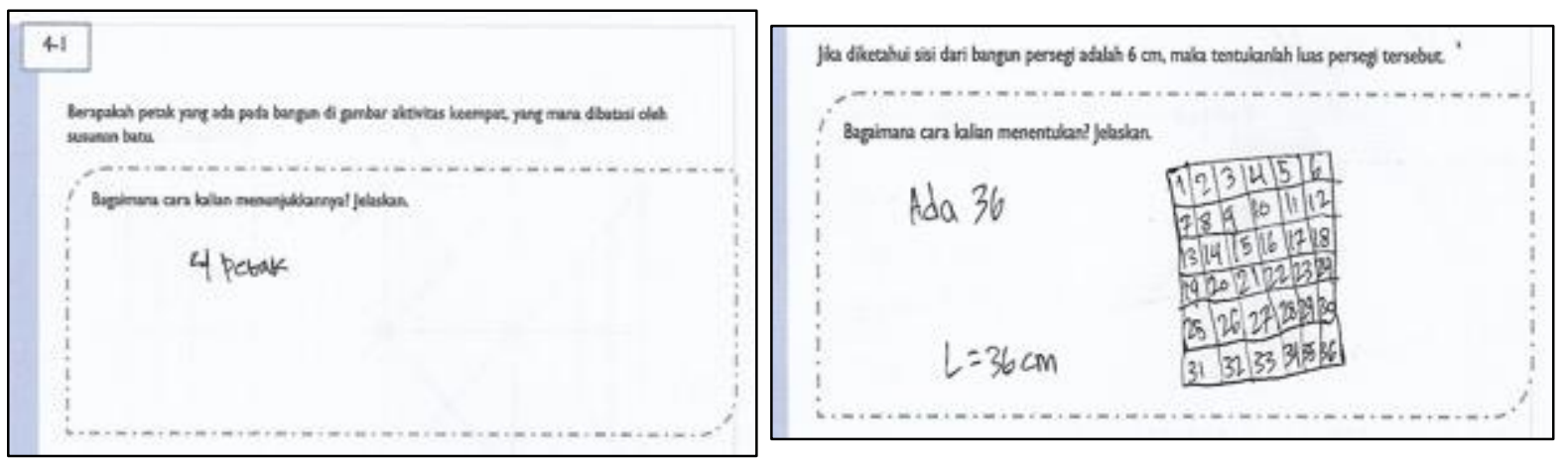

Figure 18. Students' answers of Problem 4.1 question 1 and 2 for square sides $6 \mathrm{~cm}$.

In Figure 18, the student answered that there were 4 squares following the boundaries of the stone arrangement. The four tiles on the square represented the area of the square. Students were able to identify the area of a square if they understood the length of the side was $6 \mathrm{~cm}$. As seen in Figure 18, students determined this by making 6 columns and 6 rows on a square so that several tiles were obtained in the square. Then, they assigned numbers to each of these 1 $\mathrm{cm}$ squares and counted the number, which was 36 tiles.

Students were also able to determine the area of a $7 \mathrm{~cm}$ square, that was 49 square $\mathrm{cm}$ (Figure 19). In this answer, the students determined the area of a square and wrote it in a formal form guided by the teacher. It can be identified in Dialogue 3 .

Dialogue 3

Teacher : Now, now that you know that the length of the side of a square is $4 \mathrm{~cm}$, the area of a square is $16 \mathrm{~cm}$, the question is where can you obtain $16 \mathrm{~cm}$ from?

Student : (Students answered by repeating what was identified)

Teacher : The length of the side of a square is $4 \mathrm{~cm}$ so the area of a square is sixteen, to obtain sixteen, what operation do we have to use?

Student : Multiplication.

Teacher : So that the area of a square is four times four, then, what length is $4 \mathrm{~cm}$ ?

Student : Side length.

Teacher : What is the side represented by?

Student : Denoted by $s$.

Teacher : Thus, it can be written that the area of a square is equal to $s$ times $s$.

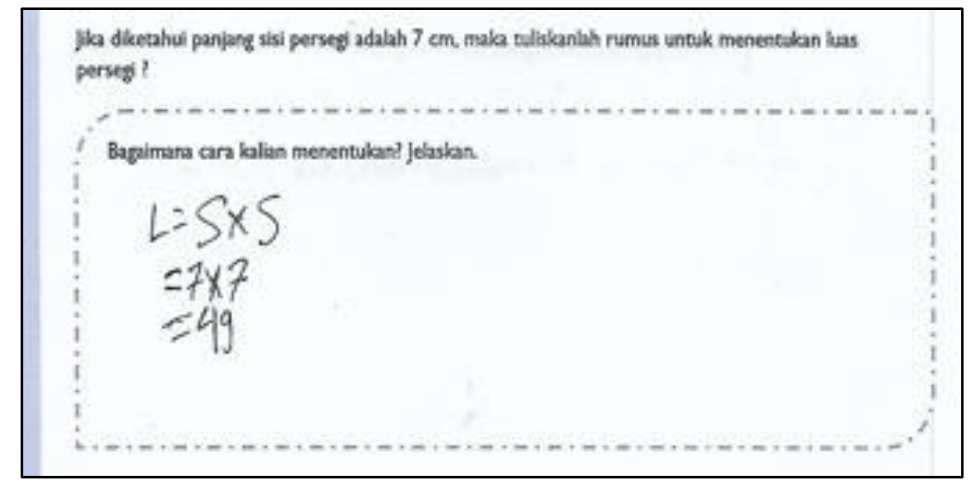

Figure 19. Students' answers of Problem 4.1 question 3. 


\section{Problem 4.2. Determining Area of the Rectangle}

Jeni and Selfi were playing the game with the position of the rocks shown (Figure 20). They connected the dots on the drawing of the Macanan game area to obtain a plane shape and color the shape. From the plane shape discovered, they were demanded to answer whether they could determine how many tiles there were in the Macanan game field, given the side length is $6 \mathrm{~cm}$, what the area of the plane shape was, if they identified that the long side was $8 \mathrm{~cm}$ and wide side was $4 \mathrm{~cm}$, what the area of the plane shape was.

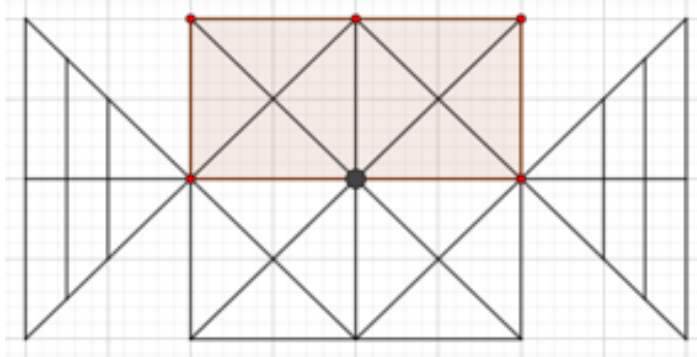

Figure 20. The Macanan game field on Problem 4.2.

After the students obtained an image of the Macanan game field, the students connected the dots on the plane. The result of connecting these points was a square, then students colored the rectangle. After that, students solved the problem and wrote the answers to the students' worksheet which can be observed in Figure 21.
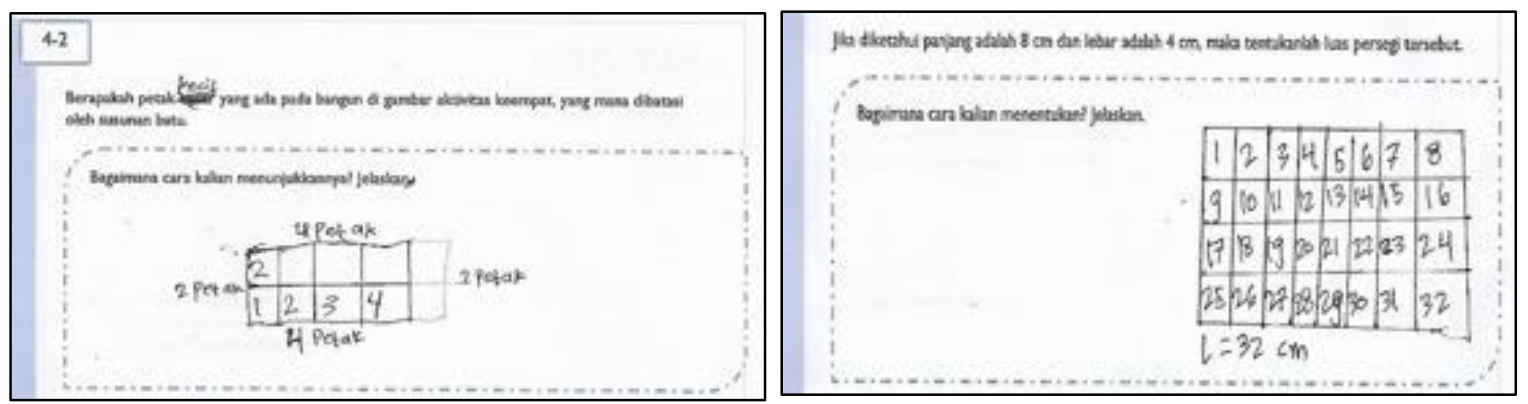

Figure 21. Students' answers of Problem 4.1 questions 1 and 2 for rectangle $8 \times 4 \mathrm{~cm}$.

Figure 21 illustrates that students could determine the number of tiles in a rectangle, that was 8 tiles. Students could also calculate the area of a rectangle by drawing a rectangle then making 8 columns and 4 rows. After that, they counted the number of tiles, 32, so that the rectangle area was 32 square $\mathrm{cm}$. 


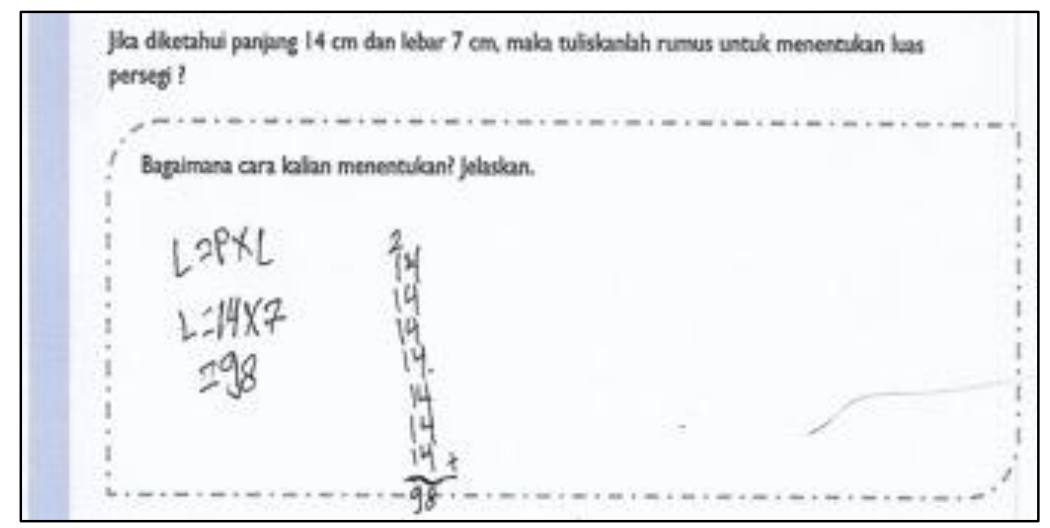

Figure 22. Students' answers of Problem 4.1 question 3 rectangle $14 \times 7 \mathrm{~cm}$.

In Figure 22, students were able to shift their strategy to determine the area of the rectangle by utilizing multiplication between the long side and the wide side. Therefore, based on the students' answers to Figures 21 and 22, it can be explained that students understood the perimeter and area of the rectangle and its formula.

The implementation results of the learning trajectory revealed that the Macanan game possesses a role as a starting point in learning squares and rectangles. In activities 1 and 2, the Macanan game area can be employed for starting points in identifying elements and properties of squares and rectangles, by identifying flat shapes in the Macanan game area, then cutting them out and sticking to the SAS which has been provided then identifying the elements and properties. In activities 3 and 4, the Macanan game area is utilized as a starting point to discover the formula for the perimeter and area of squares and rectangles. The formulas can be generated from informal to formal forms by applying the squares in the Macanan game area. As the principle in Realistic Mathematics Education (RME) is to use a context that can formulate concepts from informal to formal forms and thinking strategies for students (Sembiring et al., 2008; Hadi, 2017; Prahmana, 2017; Nasution et al., 2018, Sembiring, 2010). It is also supported by Passarella (2021), who argued that the other RME's principles, which are the heuristics of didactical phenomenology, guided reinvention, and emergent modelling, might keep student understanding to reinvent the mathematics concept in solving an experientially significant problem.

Furthermore, the results of the learning evaluation and also the answers in the SAS show that students can understand geometric concepts regarding elements, properties, perimeter, and areas of squares and rectangles. Students are also able to visualize an object with or without the help of the Macanan game context. Success in learning geometry depends on students who can understand formulas, visualize objects, observe mathematical structures, and implement problems in everyday life problems in learning geometry (Laborde, 2015; Jones \& Tzekaki, 2016; Gunhan 2014). In this study, students can visualize objects, identify and use formulas, and perform mathematical reasoning.

The result of a design research displays that with the local context and the RME approach, mathematics learning in remote area schools with limited facilities and infrastructure can still be conducted optimally. In fact, in remote areas, there are still many unique cultures and things in daily life which can be utilized as a context for learning mathematics. 


\section{Conclusion}

This study has implications for rural areas that are clearly different from students' and schools' conditions in urban areas. Recently, not many researchers have designed learning with the PMRI approach implemented in remote areas. This research provides a contribution to a new knowledge of how PMRI is applied in Indonesian remote areas, although the sample size prevents generalization of the findings. Furthermore, it contributes a small direction for mathematics knowledge and research in Indonesia.

For further research, the learning activities could be designed and compared with different approaches. It may examine the advantages and disadvantages of the learning design on other students' mathematical abilities.

\section{Acknowledgements}

We would like to thank Universitas Ahmad Dahlan and Universiti Brunei Darussalam for providing facilities and opportunities to develop this research to completion. Then, we thank Sunshine Elementary School and their teacher and students for allowing us to conduct the research.

\section{References}

Acharya, B. R. (2017). Factors affecting difficulties in learning mathematics by mathematics learners. International Journal of Elementary Education, 6(2), 8-15. https://doi.org/10.11648/j.ijeedu.20170602.11.

Angraini, P., \& Prahmana, R. C. I. (2019). Misconceptions of seventh grade students in solving geometry problem type national examinations. Journal of Physics: Conference Series, 1188(1), 012101. https://doi.org/10.1088/1742-6596/1188/1/012101.

Bakker, A. (2004). Design research in statistics education-on symbolizing and computer tools. Unpublished Ph.D. Thesis. Utrecht: The Freudenthal Institute.

Chong, M. S. F., \& Shahrill, M. (2016). The use of an emerging framework to explore students' cognitive competency. Indian Journal of Science and Technology, 9(16), 1-12. https://doi.org/10.17485/ijst/2016/v9i16/78812.

Chong, M. S. F., Shahrill, M., \& Li, H-C. (2019). The integration of a problem-solving framework for Brunei high school mathematics curriculum in increasing student's affective competency. Journal on Mathematics Education, 10(2), 215-228. https://doi.org/10.22342/jme.10.2.7265.215-228.

Cozzens, M., \& Roberts, F. S. (2020). Introductory college mathematics for the life sciences: Has anything changed? Bulletin of Mathematical Biology, 82, 87. https://doi.org/10.1007/s11538-020-00761-8.

Dharmamulya, S. (2008). Permainan Tradisional Jawa. Yogyakarta: Kepel Press.

Ernest, P. (2013). The philosophy of mathematics education. The Philosophy of Mathematics Education (pp. 1-330). Taylor and Francis. https://doi.org/10.4324/9780203058923. 
Fauziah, A., Putri, R. I. I., Zulkardi, \& Somakim. (2018). Primary school student teachers' perception to Pendidikan Matematika Realistik Indonesia (PMRI) instruction. Journal of Physics: $\quad$ Conference Series, 943(1), 012044. https://doi.org/10.1088/17426596/943/1/012044.

Febriana, M., Nurkamto, J., Rochsantiningsih, D., \& Muhtia, A. (2018). Teaching in rural Indonesian schools: Teachers' challenges. International Journal of Multicultural and Multireligious Understanding, 5(5), 11-20. https://doi.org/10.18415/ijmmu.v5i5.305.

Fitri, N. L., \& Prahmana, R. C. I. (2018). Pembelajaran luas segiempat untuk siswa kelas VII menggunakan reallotment activities. Jurnal Review Pembelajaran Matematika, 3(1), 18-28. https://doi.org/10.15642/jrpm.2018.3.1.18-28.

Freudenthal, H. (1991). Revisiting Mathematics Education: China Lectures. Dordrecht: Kluwer Academic Publishers.

Graham, K. J., \& Fennell, F. S. (2001). Principles and standards for school mathematics and teacher education: Preparing and empowering teachers. School Science and Mathematics, 101(6), 319-327. https://doi.org/10.1111/j.1949-8594.2001.tb17963.x.

Gravemeijer, K. (2020). Educational development and developmental research in mathematics education. Journal for Research in Mathematics Education, 25(5), 443-471. https://doi.org/10.5951/jresematheduc.25.5.0443.

Gravemeijer, K., \& Cobb, P. (2006). Design research from a learning design perspective. In J. van den Akker, K. Gravemeijer, S. McKenney, \& N. Nieveen (Eds.), Educational Design Research (pp. 17-51). London: Routledge.

Gravemeijer, K., \& Doorman, M. (1999). Context problems in realistic mathematics education: A calculus course as an example. Educational Studies in Mathematics, 39(1-3), 111-129. https://doi.org/10.1023/a:1003749919816.

Gravemeijer, K., \& Van Eerde, D. (2009). Design research as a means for building a knowledge base for teachers and teaching in mathematics education. The Elementary School Journal, 109(5), 510-524.

Gunhan, B. C. (2014). A case study on the investigation of reasoning skills in geometry. South African Journal of Education, 34(2), 1-19. https://doi.org/10.15700/201412071156.

Hadi, S. (2002). Effective teacher professional development for the implementation of realistic mathematics education in Indonesia. Enschede: University of Twente.

Hadi, S. (2017). Pendidikan Matematika Realistik (Teori, Pengembangan dan Implementasinya). Jakarta: PT Raja Grafindo Persada.

Haris, D., \& Putri, R. I. I. (2011). The role of context in third graders' learning of area measurement. Journal on Mathematics Education, 2(1), 55-66. https://doi.org/10.22342/jme.2.1.778.55-66

Haryani, T. M., Putri, R. I. I., \& Santoso, B. (2015). Desain pembelajaran dalam memahami konsep luas menggunakan kain motif kotak-kotak di kelas III. Kreano, Jurnal Matematika Kreatif-Inovatif, 6(1), 50-58. https://doi.org/10.15294/kreano.v6i1.4503. 
Hendayana, S., Supriatna, A., \& Imansyah, H. (2010). Indonesia's issues and challenges on quality improvement of mathematics and science education. Journal of International Cooperation in Education, 4(2), 41-51. Retrieved from http://aadcice.hiroshimau.ac.jp/ admin@aadcice.hiroshima-u.ac.jp/e/publications/sosho4_1-04.pdf.

Jaelani, A., Putri, R. I. I., \& Hartono, Y. (2013). Students' strategies of measuring time using traditional "Gasing" game in third grade of primary school. Journal on Mathematics Education, 4(1), 29-40. https://doi.org/10.22342/jme.4.1.560.29-40.

Jones, K., \& Tzekaki, M. (2016). Research on the teaching and learning of geometry. In The Second Handbook of Research on the Psychology of Mathematics Education: The Journey Continues (pp. 109-149). Sense Publishers. https://doi.org/10.1007/978-94-6300-561-6_4.

Kurniati, M., Arafat, Y., \& Mulyadi, M. (2020). Developing teacher's professionalism to improve the quality of education in remote areas. International Journal of Educational Review, 2(2), 192-202. https://doi.org/10.33369/ijer.v2i2.10991.

Kusumah, Y. S., \& Nurhasanah, F. (2017). The endless long-term program of mathematics teacher professional development in Indonesia. In Professional Development of Mathematics Teachers (pp. 33-45). Springer, Singapore. https://doi.org/10.1007/978-98110-2598-3_3.

Laborde, C. (2015). Teaching and Learning Geometry. In The Proceedings of the 12th International Congress on Mathematical Education (pp. 431-436). Springer International Publishing. https://doi.org/10.1007/978-3-319-12688-3_35.

Maschietto, M., \& Trouche, L. (2010). Mathematics learning and tools from theoretical, historical and practical points of view: The productive notion of mathematics laboratories. ZDM - International Journal on Mathematics Education, 42(1), 33-47. https://doi.org/10.1007/s11858-009-0215-3.

Muslimin, Putri, R. I. I., \& Somakim. (2012). Desain pembelajaran pengurangan bilangan bulat melalui permainan tradisional congklak berbasis pendidikan matematika realistik indonesia di kelas IV sekolah dasar. Kreano, Jurnal Matematika Kreatif-Inovatif, 3(2), 100-112. https://dx.doi.org/10.15294/kreano.v3i2.2642.

Nasrullah \& Zulkardi. (2011). Building counting by traditional game: A mathematics program for young children. Journal on Mathematics Education, 2(1), 41-54. https://doi.org/10.22342/jme.2.1.781.41-54.

Nasution, M. F., Putri, R. I. I., \& Zulkardi. (2018). Rowing sport in learning fractions of the fourth-grade students. Journal on Mathematics Education, 9(1), 69-79. https://doi.org/10.22342/jme.9.1.4270.69-80.

Noto, M. S., Priatna, N., \& Dahlan, J. A. (2019). Mathematical proof: The learning obstacles of preservice mathematics teachers on transformation geometry. Journal on Mathematics Education, 10(1), 117-126. https://doi.org/10.22342/jme.10.1.5379.117-126. 
Nurhayati, Marhayani, D. A., Chang, C. H., \& Naaranoja, M. (2019). Math anxiety analysis in Indonesian elementary school. In Communications in Computer and Information Science (Vol. 1011, pp. 292-301). Springer Verlag. https://doi.org/10.1007/978-3-030-20798-4_25.

Özerem, A. (2012). Misconceptions in geometry and suggested solutions for seventh grade students. Procedia - Social and Behavioral Sciences, 55, 720-729. https://doi.org/10.1016/j.sbspro.2012.09.557.

Passarella, S. (2021). Emergent modelling to introduce the distributivity property of multiplication: a design research study in a primary school. International Journal of Mathematical Education in Science and Technology, 1-23. https://doi.org/10.1080/0020739X.2021.1910869.

Phoenix, D. (2018). Introductory Mathematics for the Life Sciences. Introductory Mathematics for the Life Sciences. CRC Press. https://doi.org/10.1201/9781315272733.

Phonapichat, P., Wongwanich, S., \& Sujiva, S. (2014). An analysis of elementary School Students' Difficulties in Mathematical Problem Solving. Procedia - Social and Behavioral Sciences, 116, 3169-3174. https://doi.org/10.1016/j.sbspro.2014.01.728.

Plomp, T., \& Nieveen, N. (2013). Educational design research part A: An introduction. The Netherland: SLO, Enschede. Retrieved from http://international.slo.nl/publications/edr/.

Prahmana, R. C. I. (2017). Design Research (Teori dan Implementasinya: Suatu Pengantar). Jakarta: Rajawali Pers.

Prahmana, R. C. I., Zulkardi, \& Hartono, Y. (2012). Learning multiplication using Indonesian traditional game in third grade. Journal on Mathematics Education, 3(2), 115-132. https://doi.org/10.22342/jme.3.2.1931.115-132.

Prahmana, R. C. I., \& D'Ambrosio, U. (2020). Learning geometry and values from patterns: Ethnomathematics on the batik patterns of Yogyakarta, Indonesia. Journal on Mathematics Education, 11(3), 439-456. https://doi.org/10.22342/jme.11.3.12949.439-456.

Riastuti, N., Mardiyana, M., \& Pramudya, I. (2017). Students' errors in geometry viewed from spatial intelligence. Journal of Physics: Conference Series, 895(1), 012029. https://doi.org/10.1088/1742-6596/895/1/012029.

Risdiyanti, I., \& Prahmana, R. C. I. (2018). Etnomatematika: Eksplorasi dalam Permainan Tradisional Jawa. Journal of Medives: Journal of Mathematics Education IKIP Veteran Semarang, 2(1), 1-11. https://doi.org/10.31331/medives.v2i1.562.

Risdiyanti, I., Prahmana, R. C. I., \& Shahrill, M. (2019). The learning trajectory of social arithmetic using an Indonesian traditional game. Elementary Education Online, 18(4), 2094-2108. https://doi.org/10.17051/ilkonline.2019.639439.

Rowland, T. (2012). Contrasting knowledge for elementary and secondary mathematics teaching. For the Learning of Mathematics, 32(1), 16-21.

Sembiring, R. K. (2010). Pendidikan Matematika Realistik Indonesia (PMRI): Perkembangan dan tantangannya. Journal on Mathematics Education, 1(1), 11-16. https://doi.org/10.22342/jme.1.1.791.11-16. 
Sembiring, R. K., Hadi, S., \& Dolk, M. (2008). Reforming mathematics learning in Indonesian classrooms through RME. ZDM - International Journal on Mathematics Education, 40(6), 927-939. https://doi.org/10.1007/s11858-008-0125-9.

Simonson, M. (2006). Design-based research: Applications for distance education. Quarterly Review of Distance Education, 7(1), vii-viii.

UNESCO. (2008). Developing culturally contextualized mathematics resource materials: capturing local practices of Tamang and Gopali communities, A Report. Kathmandu: Lusha Press.

Van den Akker, J., Gravemeijer, K., McKenney, S., \& Nieveen, N. (2006). Educational Design Research. London: Routledge.

Van den Heuvel-Panhuizen, M. (2005). The role of context in assessment problems in mathematics. For the Learning of Mathematics, 25(2), 2-9.

Wahyuni, R. (2014). Students' Understanding in Identifying Properties of the Square and Rectangle Based on Realistic Mathematics Education. Proceeding the 2nd SEA-DR (pp. 253-262). Palembang: Universitas Sriwijaya.

Wijaya, A. (2008). Design research in Mathematics Education: Indonesian Traditional Games as Means to Support Second graders' Learning of Linear Measurement. Thesis. Utrecht: Utrecht University.

Zulkardi, \& Putri, R. I. I. (2019). New School Mathematics Curricula, PISA and PMRI in Indonesia (pp. 39-49). https://doi.org/10.1007/978-981-13-6312-2_3. 